\title{
Development and Validation of HPLC Assay Method for Marbofloxacin Determination in Veterinary Chewable Tablets
}

\author{
K. R. W. Oliveira ${ }^{a}$, R. A. Sversut ${ }^{a}$, A. K. Singh ${ }^{\mathrm{b}}$, M. S. Amaral ${ }^{\mathrm{c}}$ and N. M. Kassab ${ }^{\mathrm{a}^{*}}$ \\ "arograma de Pós-Graduação em Farmácia, Faculdade de Ciências Farmacêuticas, Alimentos e Nutrição, \\ Universidade Federal de Mato Grosso do Sul, Brazil \\ ${ }^{b}$ Departamento de Farmácia, Faculdade de Ciências Farmacêuticas, Universidade de São Paulo, São Paulo, Brazil \\ Instituto de Física, Universidade Federal de Mato Grosso do Sul, Brazil
}

Received: 16 January 2016; accepted: 22 April 2017

\begin{abstract}
The present study aimed to develop and validate an analytical method for determination of marbofloxacin (MAR) in veterinary chewable tablets. The isocratic reversed-phase chromatographic method was developed and validated using a Vertisep ${ }^{\circledR}$, RP C18 column $(150 \mathrm{~mm} \times 4.6 \mathrm{~mm}, 5.0 \mu \mathrm{m})$. The mobile phase was composed of wateracetonitrile $(55: 45, v / v)$ with $\mathrm{pH}$ adjusted to 3.0 with ortho-phosphoric acid and a flow rate set at $0.4 \mathrm{~mL} / \mathrm{min}$. The proposed method was validated for linearity in a concentration range of 2.5 to $17.5 \mu \mathrm{g} / \mathrm{mL}$ with a correlation coefficient of 0.99991 . The mean content of MAR found in chewable tablets was $104.40 \%$ with RSD below $2 \%$. The accuracy expressed as average recovery of the proposed method was $98.74 \%$, and the precision expressed as relative standard deviation among repeated analysis was $0.55 \%$. The method has adequate sensitivity with detection and quantitation limits of 0.25 and $0.81 \mu \mathrm{g} / \mathrm{mL}$, respectively. Based on the presented results and according to the ICH and AOAC guidelines on validation of analytical methods, the proposed method was considered precise, accurate with adequate sensitivity, and robust in the MAR quantitative analysis. Therefore, the method can be used in the quality control of chewable veterinary tablets containing MAR.
\end{abstract}

Keywords: quinolone, HPLC-UV, assay method, quality control

\section{Introduction}

Marbofloxacin (MAR) is a broad spectrum, second-generation fluoroquinolone drug, frequently prescribed in veterinary practices [1]. In Brazil, MAR is marketed as chewable tablets for small animals and is often prescribed against susceptible bacteria, especially in skin and urinary tract, gastrointestinal, and respiratory tract infections [2].

MAR is a carboxylic acid derivative fluoroquinolone and chemically known as 9-fluoro-2,3-dihydro-3-methyl-10-(4methyl-1-piperazinyl)-7-oxo-7H-pyrido[1,2,3ij] [1,2,4]benzoxadiazin-6-carboxylic acid (Figure 1). It has a molecular weight equivalent to $362.36 \mathrm{~g} / \mathrm{mol}$. MAR is pale yellow crystalline powder with $\mathrm{p} K_{\mathrm{a}}$ of 5.38 and 6.16 [4], soluble in water, slightly soluble in ethanol, and very soluble in methanol [3].

Several analytical methods were found in the literature, which were successfully applied in the analysis of MAR, in different matrixes. MAR and other fluoroquinolones were determined in biological samples by high-performance liquid chromatography with UV detector (HPLC-UV) $[5,6,7]$ and with fluorescence detector (HPLC-FL) $[8,9,10,11]$ and by capillary electrophoresis with UV detection (CE-UV) [12] and electrospray mass spectrometry (CE-MS) [13].

In food of animal origin, various fluoroquinolones were detected including MAR by HPLC-UV [14, 15], liquid chromatography-mass spectrometry (LC-MS) or liquid chromatographytandem mass spectrometry LC-MS/MS [16, 17, 18, 19, 20, 21], by ultra-performance liquid chromatography (UPLC) coupled to MS (UPLC-MS) [22, 23], and high-performance thin-layer chromatography [24]. Few methods were applied in the determination of MAR in infant foods [25] and in environment samples [26, 27].

*Author for correspondence: nmkassab@gmail.com.
The British Pharmacopoeia describes a HPLC method with detection in the infrared region for identification and determination of MAR and its related impurities in raw material [28, 29].

However, no analytical method was found for the determination of MAR in chewable tablets for veterinary use. Thus, the aim of this paper was to develop and validate an efficient, precise, accurate, and robust HPLC-UV method for quality control of MAR in chewable veterinary tablets.

\section{Experimental}

Material and Reagents. The raw material of MAR (100.2\%) was kindly provided by a local veterinary industry (CEVA LTDA, São Paulo - Brazil) and was used as a reference standard, without further purification. Chewable tablet samples (Marbopet ${ }^{\circledR}$ $27.5 \mathrm{mg}, \mathrm{CEVA})$ were acquired from the local market. The samples and standard were stored in light-resistant containers.

The HPLC-grade acetonitrile (Vetec Química Fina Ltda, Rio de Janeiro, Brazil), ortho-phosphoric acid (Synth, Brazil), and ultrapure water obtained from Direct-Q 3 UV (EMD Millipore) were used in the analyses.

Instrumentation and Chromatographic Conditions. All analyses were carried out on a Dionex ${ }^{\circledR}$ HPLC system, model ultimate 3000 (Thermo fisher scientific, USA), equipped with an<smiles>CN1CCN(c2c(F)cc3c(=O)c(C(=O)O)cn4c3c2OCN4C)CC1</smiles>

Figure 1. Molecular structure of MAR

This is an open-access article distributed under the terms of the Creative Commons Attribution-NonCommercial 4.0 International License (https://creativecommons.org/licenses/by-nc/4.0/), which permits unrestricted use, distribution, and reproduction in any medium for non-commercial purposes, provided the original author and source are credited, a link to the CC License is provided, and changes - if any - are indicated. 
UV diode array detector (photodiode array). The chromatograms were obtained in the software Chromeleon ${ }^{\circledR} 7.1$.

The chromatographic conditions were optimized, and adequate separations were obtained with a Vertisep ${ }^{\circledR} \mathrm{C}-18$ column $(150 \mathrm{~mm} \times 4.6 \mathrm{~mm}, 5 \mu \mathrm{m})$. The system operated in the isocratic mode with a mobile phase composed of acetonitrilewater $(55: 45 v / v ; \mathrm{pH} 3.0$; adjusted with ortho-phosphoric acid), with a flow rate of $0.4 \mathrm{~mL} / \mathrm{min}$. The injection volume was set at $20 \mu \mathrm{L}$, and UV detection at $298 \mathrm{~nm}$. All analyses were conducted at room temperature $\left(24 \pm 2{ }^{\circ} \mathrm{C}\right)$.

Standard Solution Preparation. A mass equivalent to $10.0 \mathrm{mg}$ of MAR standard was transferred to a $100-\mathrm{mL}$ volumetric flask, and the volume was completed with the mobile phase. A 15-min ultrasound bath was used to solubilize the drug, and the final concentration was $100.0 \mu \mathrm{g} / \mathrm{mL}$. The last solution was diluted again in the mobile phase to obtain final concentration of $25.0 \mu \mathrm{g} / \mathrm{mL}$.

Sample Solution Preparation. Twenty tablets were weighed and were crushed to obtain homogeneous powder. A mass equivalent to $10 \mathrm{mg}$ of MAR was weighed and transferred to a $100 \mathrm{~mL}$ volumetric flask. The content was solubilized in mobile phase in an ultrasound water bath for $15 \mathrm{~min}$ and volume was completed with same solvent. An aliquot of $25 \mathrm{~mL}$ was transferred to a $100 \mathrm{~mL}$ volumetric flask and volume was completed with mobile phase. The final concentration was $25.0 \mu \mathrm{g} / \mathrm{mL}$.

Solutions for Calibration Curve. The MAR calibration curve was constructed from a standard solution of $25.0 \mu \mathrm{g} / \mathrm{mL}$, from which successive dilutions were made using aliquots of this solution to obtain concentrations in the range of $2.5 \mu \mathrm{g} / \mathrm{mL}$ to $17.5 \mu \mathrm{g} / \mathrm{mL}$.

Method Validation. The proposed method was validated according to the International Conference on Harmonization (ICH) and AOAC guidelines on validation of analytical methods $[30,31]$. The analyzed parameters such as specificity, precision, accuracy, linearity, robustness, limit of detection, and quantitation are briefly described in the following sections [30, 31].

Specificity. The selectivity of the proposed method was demonstrated through the analysis of a placebo (excipients mixture) equivalent to commercial formulation, through proposed method.

Linearity. The linearity of the method was determined through the calibration curve, constructed in the concentration range from $2.5 \mu \mathrm{g} / \mathrm{mL}$ to $17.5 \mu \mathrm{g} / \mathrm{mL}$. Linearity parameters were calculated using the least squares method.

Detection and Quantitation Limits. The detection limit (LOD) and quantitation limit (LOQ) are defined as the lowest concentration that can be detected and quantified with acceptable accuracy and precision, respectively. The estimated LOD and LOQ concentrations were crosschecked by actual analysis by proposed method.

Precision. The precision of the method is its ability to repeat the same responses when a single sample is analyzed in replicates, on the same day (intra-day) or on subsequent days (inter-day). The accuracy of the proposed method was estimated by analyzing replicates of a $10.0 \mu \mathrm{g} / \mathrm{mL}$ sample solution, and the result will be expressed as relative standard deviation (RSD) between the values found.

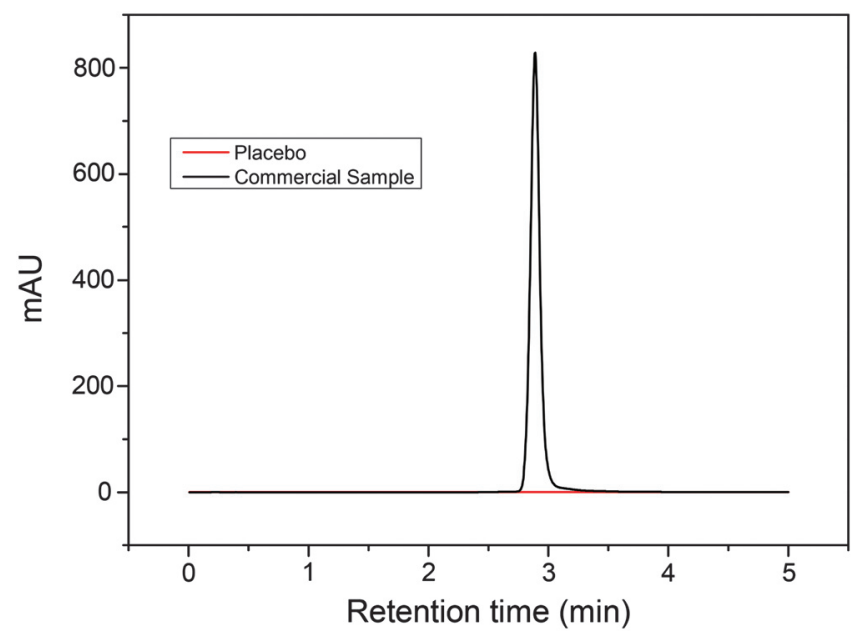

Figure 2. MAR and placebo's mix chromatogram obtained in the analysis of MAR and placebo mixture. Chromatographic conditions were obtained using a VertiSep ${ }^{\circledR} \mathrm{C} 18$ column $(150 \mathrm{~mm} \times 4.6 \mathrm{~mm}, 5 \mu \mathrm{m})$ with a mobile phase composed of acetonitrile-water $(55: 45, v / v)$ with $\mathrm{pH} 3.0$, adjusted with ortho-phosphoric acid. The mobile phase was pumped at a flow rate of $0.4 \mathrm{~mL} / \mathrm{min}$ and a fixed injection volume of $20 \mu \mathrm{L}$

Accuracy. The accuracy of the proposed method was estimated by the recovery of the standard from fortified sample solutions. A series of sample solutions were spiked with standard solution to obtain final solution concentrations of $10.0,12.0$, and $14.0 \mu \mathrm{g} / \mathrm{mL}$. The percent recovery of the standard from the sample solution demonstrates the accuracy of the proposed method.

Robustness. The robustness of the method was determined by deliberate changes in the analytical parameters. The capacity of the proposed method to resist against these deliberate changes demonstrates the robustness of the proposed method. The following parameters were selected to evaluate robustness: mobile phase composition $( \pm 1 v / v)$, mobile phase $\mathrm{pH}( \pm 0.1)$, flow rate $( \pm 0.03 \mathrm{~mL} / \mathrm{min})$, column temperature $\left( \pm 2{ }^{\circ} \mathrm{C}\right)$, and column type (Vertisep ${ }^{\circledR} \mathrm{C} 18$ and Kinetex $\left.{ }^{\circledR} \mathrm{C} 18\right)$.

\section{Results and Discussion}

A simple HPLC assay method was developed and applied in the analysis of MAR in veterinary chewable tablets. The method was fully validated, and the assay parameters are presented in the following section.

The specificity of the method is indicated from chromatograms obtained in the analysis of standard, sample, and placebo solutions (Figure 2). There was no interfering peak with the same retention time as that of main MAR peak. Moreover, peak purity data (not shown) proves the specificity of the proposed method.

The proposed method is linear, according to the results obtained by means of the calibration curve in the concentration range from $2.5 \mu \mathrm{g} / \mathrm{mL}$ to $17.5 \mu \mathrm{g} / \mathrm{mL}$. The results obtained in the MAR analysis presented a linear correlation between the

Table 1. Results obtained in intra- and inter-day precision analysis

\begin{tabular}{|c|c|c|c|c|}
\hline \multirow{3}{*}{$\begin{array}{l}\text { Theoretical } \\
\text { concentration } \\
(\mu \mathrm{g} / \mathrm{mL})\end{array}$} & \multicolumn{4}{|c|}{ Experimental concentration $\pm \mathrm{RSD}(\%)^{c}$} \\
\hline & \multicolumn{3}{|c|}{ Repeatability $^{a}$} & \multirow{2}{*}{$\begin{array}{l}\text { Intermediate } \\
\text { precision }^{b}\end{array}$} \\
\hline & Day 1 & Day 2 & Day 3 & \\
\hline 10.0 & $104.74 \% \pm 0.34$ & $104.33 \% \pm 0.07$ & $104.14 \% \pm 0.26$ & $104.4 \pm 0.29$ \\
\hline $\begin{array}{l}{ }^{a} \text { Average of } \\
{ }^{b} \text { Average of } \\
{ }^{c} \text { Relative st }\end{array}$ & & & & \\
\hline
\end{tabular}


Table 2. Results obtained in the recovery test

\begin{tabular}{lccc}
\hline $\begin{array}{l}\text { Final theoretical } \\
\text { concentration } \\
(\mu \mathrm{g} / \mathrm{mL})\end{array}$ & $\begin{array}{c}\text { Final experimental } \\
\text { concentration } \\
(\mu \mathrm{g} / \mathrm{mL})\end{array}$ & $\begin{array}{c}\text { Results } \\
(\%)\end{array}$ & Mean $\pm \mathrm{RSD}^{b}$ \\
\hline 10.0 & 10.01 & 100.1 & \\
12.0 & 11.96 & 99.66 & $99.54 \pm 0.55$ \\
14.0 & 13.84 & 98.86 & \\
${ }^{a}$ Average of 3 determinations. & & \\
${ }^{b}$ Relative standard deviation. & & \\
\hline
\end{tabular}

Table 3. Results obtained in the evaluation of robustness test

\begin{tabular}{|c|c|c|c|c|}
\hline \multicolumn{2}{|c|}{$\begin{array}{l}\text { Chromatographic } \\
\text { conditions }\end{array}$} & \multicolumn{3}{|c|}{ Parameters } \\
\hline Factor $^{a}$ & Level & Peak area & Retention time (min) & Asymmetry \\
\hline \multicolumn{5}{|c|}{ A: $\%$ acetonitrile in the mobile phase $(v / v)$} \\
\hline 56 & +1 & 60.08 & 2.96 & 1.06 \\
\hline 55 & 0 & 60.28 & 2.98 & 1.03 \\
\hline 54 & -1 & 59.24 & 2.95 & 1.08 \\
\hline \multicolumn{5}{|c|}{ B: Mobile phase $\mathrm{pH}$} \\
\hline 3.01 & +0.01 & 66.44 & 2.96 & 1.04 \\
\hline 3.00 & 0.00 & 60.28 & 2.98 & 1.03 \\
\hline 2.99 & -0.01 & 57.18 & 2.94 & 0.99 \\
\hline \multicolumn{5}{|c|}{ C: Mobile phase flow rate (mL/min) } \\
\hline 0.43 & +0.03 & 55.30 & 2.76 & 1.08 \\
\hline 0.40 & 0.00 & 60.28 & 2.98 & 1.03 \\
\hline 0.37 & -0.03 & 63.50 & 3.21 & 1.08 \\
\hline \multicolumn{5}{|c|}{ D: Temperature $\left({ }^{\circ} \mathrm{C}\right)$} \\
\hline $27^{\circ} \mathrm{C}$ & +2 & 60.28 & 2.98 & 1.02 \\
\hline $25^{\circ} \mathrm{C}$ & 0 & 60.28 & 2.98 & 1.03 \\
\hline $23^{\circ} \mathrm{C}$ & -2 & 60.39 & 2.98 & 1.04 \\
\hline \multicolumn{5}{|l|}{ E: Column } \\
\hline Vertisep $^{(}$ & - & 60.28 & 2.98 & 1.03 \\
\hline $\mathrm{C} 18$ & & & & \\
\hline Kinetex ${ }^{\circledR} \mathrm{C} 18$ & - & 30.42 & 3.76 & 0.9 \\
\hline
\end{tabular}

injected concentration and its peak area with a correlation coefficient $\left(r^{2}\right)$ greater than 0.9999 and a line equation of $y=$ $5.3434 x+0.2334$.

The experimental values of LOD and LOQ for MAR were $0.25 \mu \mathrm{g} / \mathrm{mL}$ and $0.81 \mu \mathrm{g} / \mathrm{mL}$, respectively.

The RSD values obtained in intra- and inter-day analysis of MAR, by proposed method, were below $2 \%$. This indicates an excellent precision of the proposed method (Table 1).

The average recovery of standard from sample matrix was between $98.0-102.0 \%$, which indicates acceptable accuracy of the proposed method. Moreover, the standard variation among the obtained results was below $2 \%$ (Table 2 ).

The results obtained in the evaluation of robustness (Table 3) showed that a small variation in the composition of the mobile phase, its $\mathrm{pH}$, flow rate, column temperature, and C18 column packing has an insignificant impact on the MAR chromatograms. There was a slight variation in the retention time, as well as asymmetry of MAR peak when different column type was used on the system (Vertisep ${ }^{\circledR}$ C18 verses Kinetex ${ }^{\circledR}$ C18). The influence of column temperature on retention time and peak asymmetry is unnoticeable.

Moreover, such small deliberate changes in the mobile phase, column type, and temperature do not have negative influence on the quantitative determination of drug in chewable veterinary tablets.

\section{Conclusions}

A reversed-phase HPLC-UV method was successfully developed, validated, and applied in the analysis of MAR in veterinary chewable tablets. The obtained data on validation proves that the proposed method has adequate sensitivity, and analysis can be done, with accuracy and precision, in accordance to the AOAC and ICH guidelines. The method is especially useful in quick assays for determining content uniformity of MAR in quality control laboratories, due to short analysis time $(<3.5 \mathrm{~min})$ and simple binary mobile phase.

\section{References}

1. Mahmood, A. H.; Medley, G. A.; Grice, J. E.; Liu, X.; Roberts, M. S. Determination of trovafloxacin and marbofloxacin in sheep plasma samples by hplc using uv detection J. Pharm. Biomed. Anal. 2012, 62, 220-221.

2. http://www.ceva.com.br/content/search?SearchText=marbopet (accessed on 15.April.2014)

3. http://bp2012.infostar.com.cn/Bp2012.aspx?a $=$ query\&title $=\%$ 22Marbofloxacin $\% 22 \& \mathrm{tab}=\mathrm{a}-\mathrm{z}+\mathrm{index} \& \mathrm{l}=\mathrm{M} \& \mathrm{xh}=19$ (accessed on 15.04.2014).

4. http://www.chemicalize.org/structure/\#!mol=marbofloxacin\&source $=\mathrm{fp}$ (accessed on 21.05.2014).

5. Jiménez-Lozano, E.; Marqués, I.; Barrón, D.; Beltrán, J. L.; Baarbosa, J. Anal. Chim. Acta. 2002, 464, 37-45.

6. Barbosa, J.; Barrón, D.; Cano, J.; Jiménez-Lozano, E.; Sanz-Nebot, V.; Toro, I. J. Pharm. Biomed. Anal. 2001, 24, 1087-1098.

7. Mahamood, A. H.; Medley, G. A.; Grice, J. E.; Liu, X.; Roberts, M. S. J. Pharm. Biomed. Anal. 2012, 62, 220-223.

8. Garcia, M. A.; Solans, C.; Amarayona, J. J.; Rueda, S.; Bregante, M. A. J. Chromatogr. B. 1999, 729, 157-161.

9. Milanova, A.; Petrova, D. K.; Stanilova, S. A. J. Liq. Chromatogr. R T. 2012, 35, 1130-1139.

10. Cañada-Cañada, F.; Arancibia, J. A.; Escandar, G. M.; Ibañez, G. A.; Mansilla, A. E.; Muñoz de La Peña, A.; Olivieri, A. C. J. Chromatogr. A. 2009, 1216, 4868-4876.

11. González, C.; Moreno, L.; Small, J.; Jones, D. G.; Bruni, S. F. S. Anal. Chim. Acta. 2006, 560, 227-234.

12. Hernández, M.; Borrull, F.; Calull, M. Trac-Trend Anal. Chem. 2003 22, 416-420.

13. MacCourt, J.; Bordin, G.; Rodríguez, A. R. J. Chromatogr. A. 2003, 990, 259-269.

14. Galarini, R.; Fioroni, L.; Angelucci, F.; Tovo, G. R.; Cristofani, E. J. Chromatogr. A. 2009, 1216, 8158-8164.

15. Marazuela, M. D.; Moreno-Bondi, M. C. J. Chromatogr. A. 2004, $1034,25-32$.

16. Di Garcia, A.; Nazzari, M. J. Chromatogr. A. 2002, 974, 53-89.

17. Hoff, N. V.; De Wasch, K.; Okerman, L.; Reybroeck, W.; Poelmans, S.; Noppe, H.; De Brabander, H. Anal. Chim. Acta. 2005, 529, 265-272.

18. Kaklamanos, G.; Vincent, U.; Von Holst, C. J. Chromatogr. A. 2013, 1293, 60-74.

19. Dasenaki, M. E.; Thomaidis, N. S. Anal. Chim. Acta. 2015, 880, 103-121. 20. Rubies, A.; Vaquerizo, R.; Centrich, F.; Compaño, R.; Granados, M.; Prat, M. D. Talanta 2007, 72, 269-276.

21. Cepurnieks, G.; Rjabova, J.; Zacs, D.; Baartkevics, V. J. Pharm. Biomed. Anal. 2015, 102, 184-192.

22. Zhan, J.; Yu, X. J.; Zhong, Y. Y.; Zhang, Z. T.; Cui, X. M.; Peng, J. F.; Feng, R.; Liu, X. T.; Zhu, Y. J. Chromatogr. B. 2012, 906, 48-57.

23. Chen, Y.; Schwack, W. J. Chromatogr. A. 2014, 1356, $249-257$.

24. Shao, B.; Chen, D.; Zhang, J.; Wu, Y.; Sun, C. J. Chromatogr. A. 2009, 1216, 8312-8318

25. Kemper, N. Ecological Indicators 2008, 8, 1-13.

26. Saifrtová, M.; Nováková, L.; Lino, C.; Pena, A.; Solich, P. Anal. Chim. Acta. 2009, 649, 158-179.

27. Prat, M. D.; Benito, J.; Compaño, R.; Hernández-Arteseros, J. A.; Granados, M. J. Chromatogr. A. 2004, 1041, 27-33.

28. Indian Pharmacopoeia. The Controller of Publication, $5^{\text {th }}$ ed. New Delhi, 2007.

29. United States Pharmacopeia. United States Pharmacopeial Convention, $32^{\mathrm{a}}$ ed. Rockville, United States of America, 2008.

30. AOAC. Association of Official Analytical Chemists Official Methods of Analysis, 18 ed. 2006.

31. Harmonized Tripartite Guideline. Validation of analytical methods: definitions and terminology, ICH Topic Q2A. London, 1994, 6p. 